\title{
TWO NEW TAXA OF RHODODENDRON (ERICACEAE) FROM VIETNAM
}

\author{
R. A. Baines ${ }^{1 \star}$, D. F. Chamberlain'1, V. D. Nguyen ${ }^{2,3}$ \& B. H. Quang ${ }^{2}$
}

Two new taxa from Vietnam are described and illustrated: Rhododendron tephropeploides, in subsection Tephropepla, and $R$. chunii subsp. vietnamense, in subsection Tsutsusi.

Keywords. Ericaceae, Phan Xi Păng, Rhododendron chunii subsp. vietnamense, Rhododendron tephropeploides, Vietnam.

Received 2 October 2020 Accepted 9 April 2021 Published 28 June 2021

\section{Introduction}

In recent years, several new species of Rhododendron have been described from Vietnam. These include Rhododendron suoilenhense D.F.Chamb., N.T.T.Huong \& Rushforth and $R$. rushforthii Argent \& D.F.Chamb.

In collaboration with researchers from the Vietnamese Institute of Ecology and Biological Resources (IEBR), staff from the Royal Botanic Garden Edinburgh, Royal Botanic Gardens, Kew, Longwood Gardens, and the University of British Columbia undertook a joint expedition to Northern Vietnam in 2014. The aim of this expedition was to collect a range of species distributed in Northwest Vietnam, particularly on the Hoang Lien Son mountain range, for research and ex situ conservation. Material collected included living material, seed, herbarium specimens and DNA samples. The genus Rhododendron was a particular focus, reflecting the research and conservation interests of the group. Some of the plants raised from these seeds at Logan, Kew and the Yorkshire Arboretum first flowered in 2016. Among these, we identified two hitherto undescribed rhododendron taxa.

Mackay et al. (2018) recognise 47 Rhododendron taxa from Vietnam. However, botanical exploration of the high mountains of northern Vietnam has been very limited, so our understanding of the diversity and distribution of Rhododendron species in the region remains rudimentary (Gibbs et al., 2011). Northern Vietnam is at the southeastern end of the Sino-Himalayan mountain range and is an important part of the Indo-Burma biodiversity hotspot for plants (Critical Ecosystem Partnership Fund, 2020). There are also phytogeographical affinities with the montane flora of South and Southeast China.

\footnotetext{
${ }^{1}$ Royal Botanic Garden Edinburgh, 20A Inverleith Row, Edinburgh EH3 5LR, Scotland, UK.

${ }^{2}$ Institute of Ecology and Biological Resources, Vietnam Academy of Science and Technology, 18 Hoang Quoc Viet, Nghia Do, Cau Giay, Hanoi, Vietnam.

${ }^{3}$ Graduate University of Science and Technology, Vietnam Academy of Science and Technology, 18 Hoang Quoc Viet Street, Cau Giay, Hanoi, Vietnam.

* Corresponding author. E-mail: rbaines@rbge.org.uk.
} 


\section{Taxonomic treatment}

Rhododendron tephropeploides R.A.Baines \& D.F.Chamb., sp. nov. (subsect. Tephropepla) Similar to the allied Rhododendron tephropeplum Balf.f. \& Farrer, a species from Northeast India, northern Myanmar and Southwest China, but differs in the dimorphic scales on the lower leaf surfaces; the smaller, 1-mm calyx lobes; the larger funnel-shaped, whitish to pale pink 30-35 mm corollas that are glabrous on the outer surfaces; and the glabrous stamens. - Type: Cultivated at the RBGE, Logan Botanic Garden (accession number 20150482), 23 iv 2019, Baines 71 (holotype HN, isotype E). Figures 1, 2.

Shrub to $1.2 \mathrm{~m}$ tall; bark longitudinally peeling, mahogany. Leaves narrowly elliptic, subacute, apiculate, base cuneate, lamina (30-)50-60 × 20-25 mm, dark green above, lower surface grey, papillose; scales sunk in pits, dense, to twice their diameter apart, dimorphic, the smaller whitish, the larger rufous and scattered; petioles 50-90 mm, densely lepidote, otherwise glabrous. Inflorescence terminal, 3- to 6-flowered, rachis short. Calyx lobes 5-orbicular, c. $1 \mathrm{~mm}$ long, scaly below. Corolla funnel-shaped, whitish to pale pink, 30-35 mm long, tube $15 \mathrm{~mm}$ long, glabrous on outer and inner surfaces. Filaments glabrous. Ovary lepidote; style impressed, lepidote at base. Capsule ovoid, c.7 $\times 2-3 \mathrm{~mm}$, densely scaly.
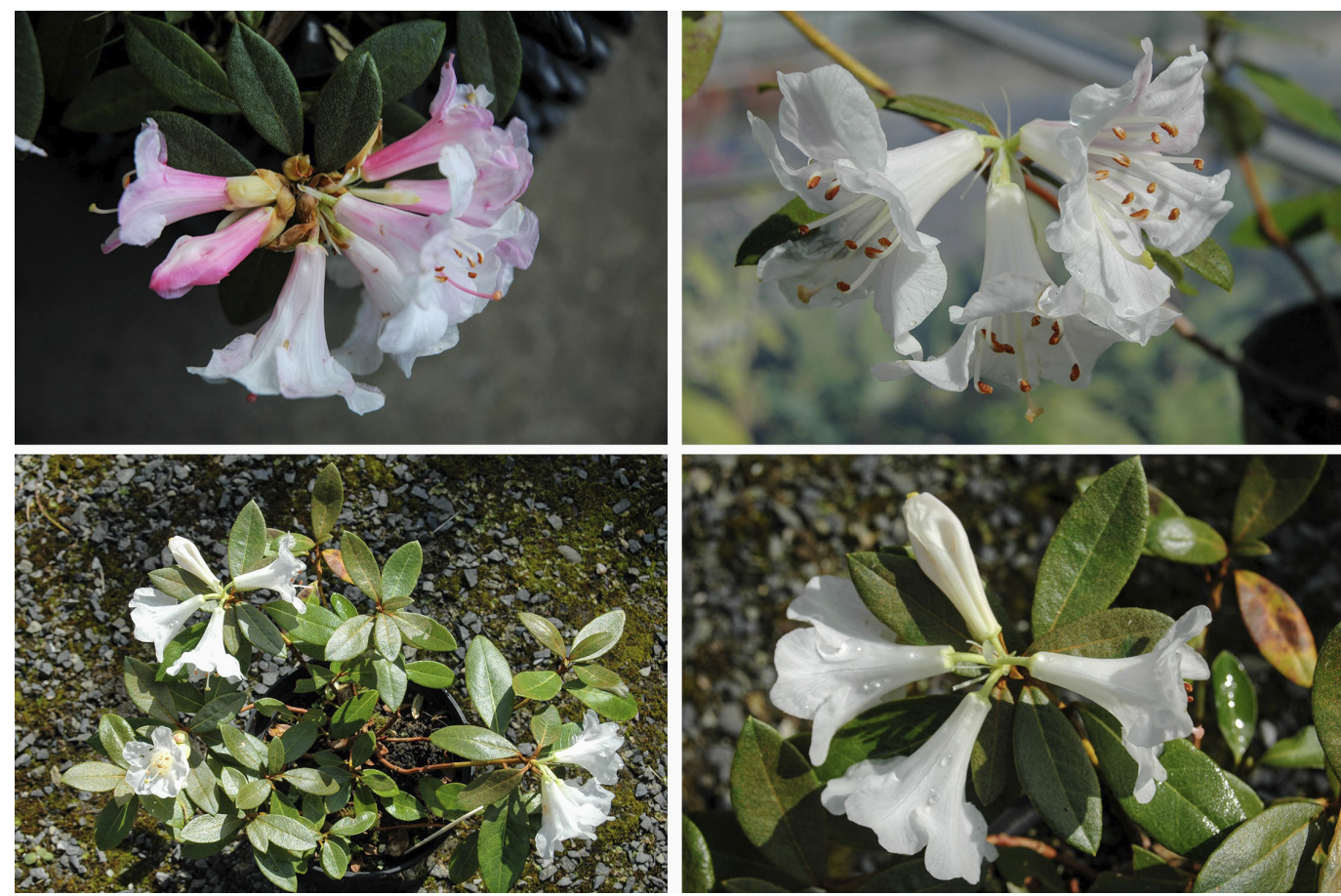

Figure 1. Rhododendron tephropeploides R.A.Baines \& D.F.Chamb., sp. nov. RBGE accession no. 20150482 flowering at Logan Botanic Garden. Photographs: R. A. Baines. 

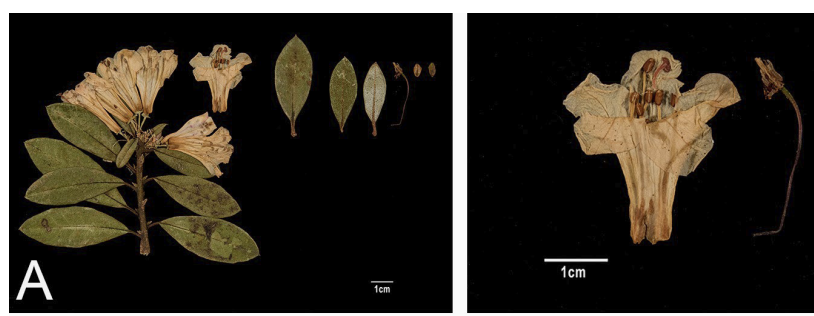

00

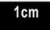

B
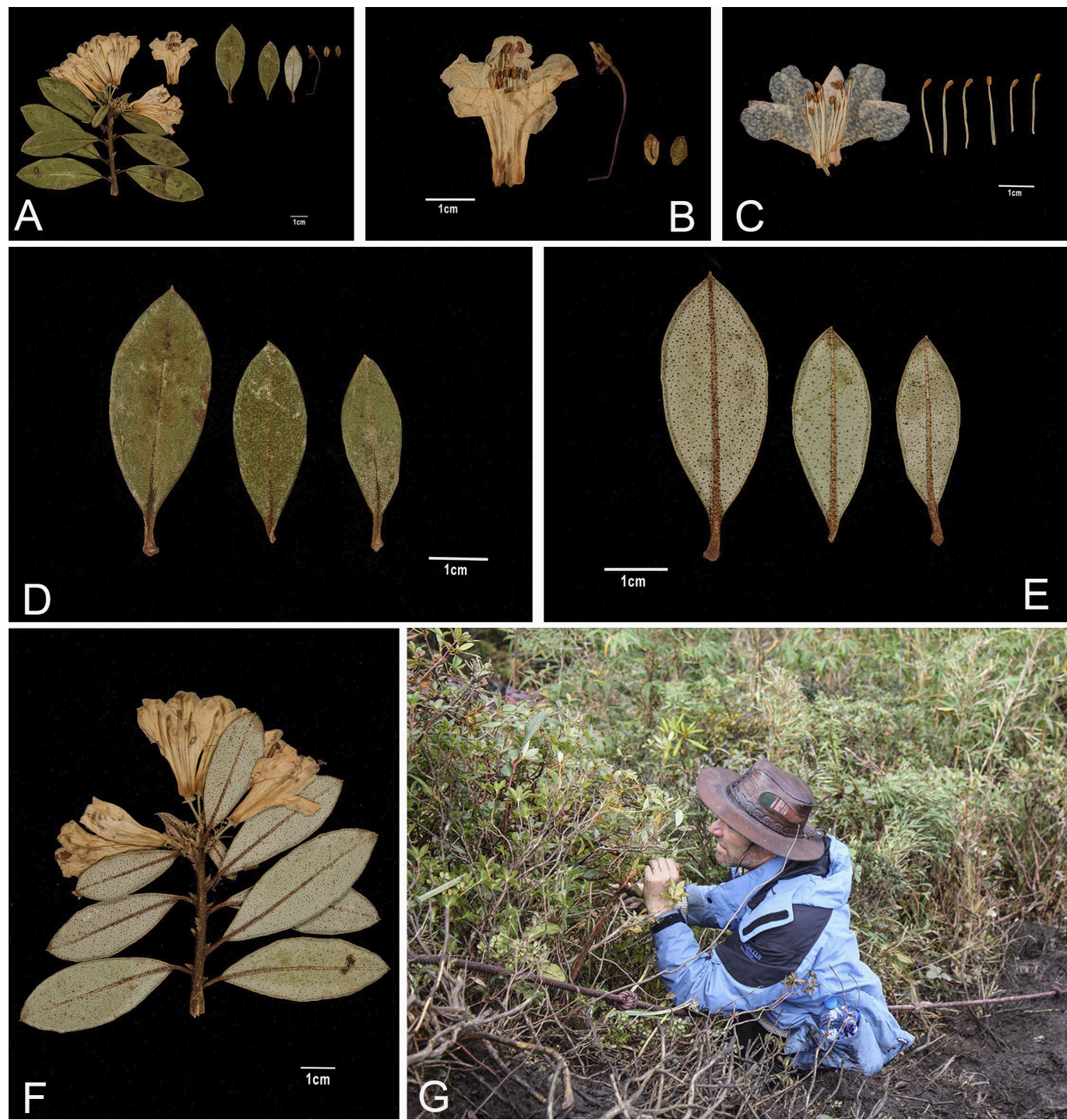

Figure 2. Rhododendron tephropeploides R.A.Baines \& D.F.Chamb., sp. nov. A, Flowering stem in cultivation; $\mathrm{B}$, floral parts highlighting stigma, style and minimal calyx; $\mathrm{C}$, floral parts highlighting stamens; D, adaxial leaf surfaces and petioles; $E$, abaxial leaf surfaces and petioles; $F$, abaxial view of flowering stem in cultivation; G, habitat. Photographs: L. Wilson.

Ecology. Temperate montane cloud forest, in wet thin soil with high humus content and high humidity. The surrounding vegetation is characterised by Hydrangea, Illicium and Rhododendron.

Phenology. The above description has been prepared from cultivated plants grown at Logan 
Botanic Garden from seeds collected in the wild in November 2014. The normal flowering time is mid to late April.

Conservation status. Data Deficient (DD) (IUCN Standards and Petitions Subcommittee, 2019). Two populations were discovered on Phan Xi Păng Mountain. One of these was at threat from erosion near a public path.

Cultivation. Rhododendron tephropeploides should be grown in partial shade but will tolerate exposed conditions down to a minimum temperature of approximately $-8^{\circ} \mathrm{C}$. It requires damp, acidic soils that are freely draining but high in organic matter. When propagated from seed it can produce flowers in its third year and should reach a maximum height of $2 \mathrm{~m}$.

Additional specimen examined. VIETnAM. Lào Cai Province: Sa Pa District, Phan Xi Păng Mountain,

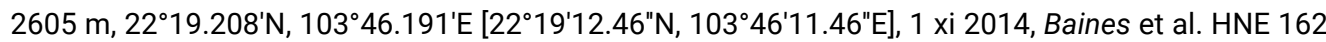
(source of seeds for RBGE accession 20150482) (E, HN, K).

The differences between Rhododendron tephropeploides and R. tephropeplum are summarised in the Table.

Rhododendron chunii W.P.Fang subsp. vietnamense R.A.Baines \& D.F.Chamb., subsp. nov. (subsect. Tsutsusi)

Rhododendron chunii subsp. chunii differs from the new subspecies in the young stems that bear appressed bristles that apparently lack the stipitate glands of subsp. vietnamense, and in the outer surface of the corolla tube that is glandular. - Type: Cultivated at RBGE, Logan Botanic Garden (accession number 20150480), 23 iv 2019, Baines 73 (holotype HN, isotype E). Figures 3, 4.

Small shrub, to $2 \mathrm{~m}$; young shoots covered with erectopatent bristles, stipitate glands and flattened strigose red-brown hairs. Leaves monomorphic, coriaceous, persistent, elliptic to oblong-ovate, $1-2 \times 0.5-0.9 \mathrm{~cm}$, twice as long as broad, apex acuminate, base broadly cuneate, margin entire, upper surface strigose, lower surface paler, strigose, especially on midrib; petiole 2-3 mm, strigose. Inflorescence 2- to 3-flowered; pedicels 5-7 mm, densely brown-strigose. Calyx strigose; lobes 1-2 mm, oblanceolate. Corolla funnel-shaped, lilacpurple, upper lobes flecked, 9-10 mm; tube $6 \times 3 \mathrm{~mm}$, with 5 rows of glands on the outer surface, glandular within but glabrous outside. Stamens 5 , subequal, filaments minutely hairy

Table. Comparison of Rhododendron tephropeplum and $R$. tephropeploides

\begin{tabular}{lll}
\hline Character & $R$. tephropeplum & $R$. tephropeploides \\
\hline Calyx lobes & $5-7(-8) \mathrm{mm}$, orbicular to oblong & $1 \mathrm{~mm}$, orbicular, dimorphic \\
Corolla & Campanulate, (17-)20-24 mm & Funnel-shaped, 30-35 mm \\
Stamen filaments & Pubescent towards base & Entirely glabrous \\
Leaf scales & Unequal, not dimorphic & Dimorphic \\
\hline
\end{tabular}



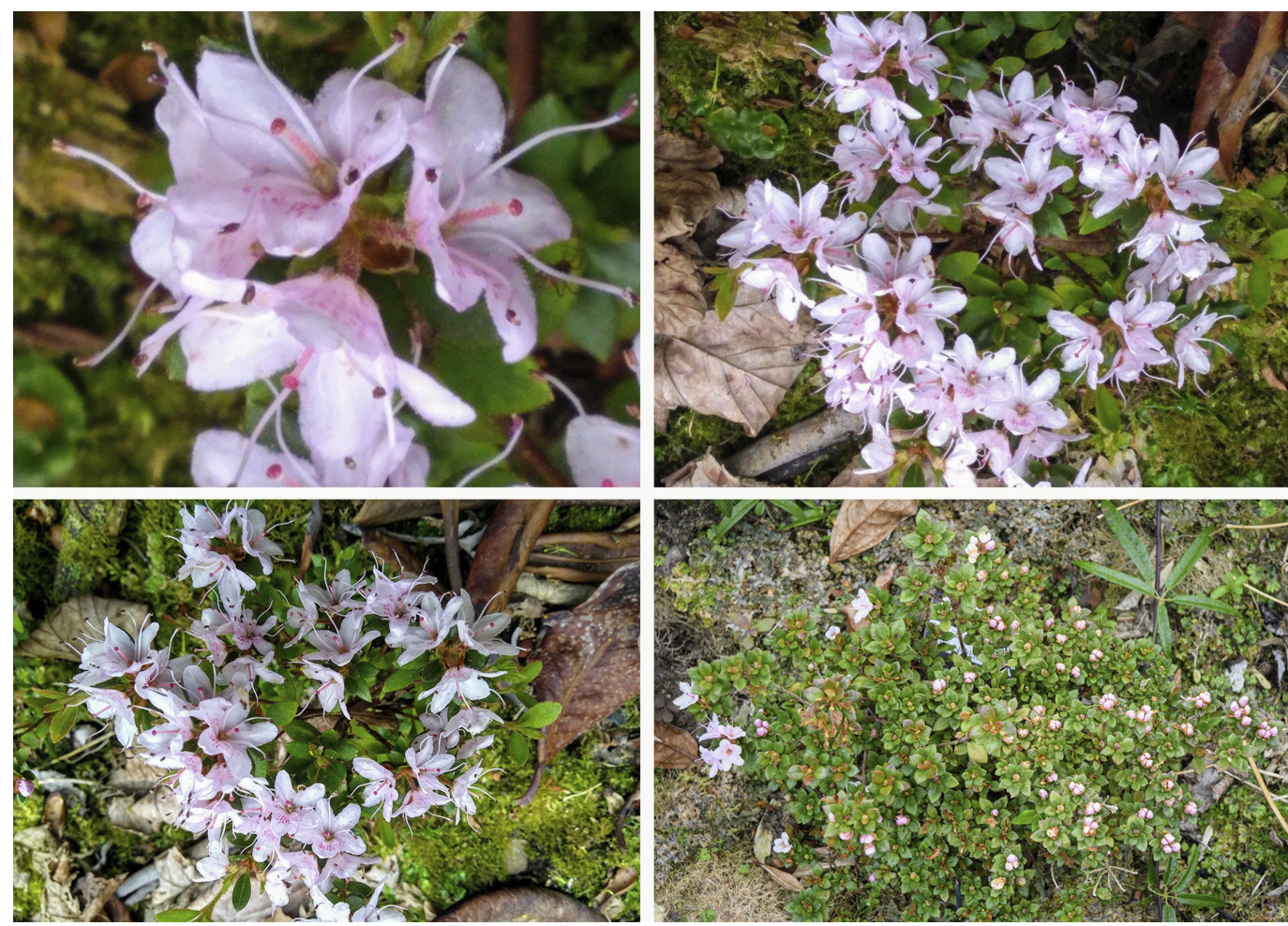

Figure 3. Rhododendron chunii subsp. vietnamense R.A.Baines \& D.F.Chamb., subsp. nov. HNE 160, RBGE accession no. 20150480, flowering at Logan Botanic Garden. Photographs: R. A. Baines.

below. Ovary densely covered in fine brown hairs; style covered with fuscous setose hairs and glands in lower half. Capsule ovoid $5 \times 4 \mathrm{~mm}$, strigose.

Ecology. Temperate montane cloud forest, in wet thin soil with high humus content and high humidity. The surrounding vegetation is characterised by Enkianthus, Pieris and Rhododendron.

Phenology. The above description has been prepared from cultivated plants grown at Logan Botanic Garden from seeds collected in the wild in November 2014. The normal flowering time is mid to late April.

Conservation status. Data Deficient (DD) (IUCN Standards and Petitions Subcommittee, 2019). At least four small populations are known on Phan Xi Păng Mountain, within the Hoang Lien National Park. We treat the conservation assessment of this subspecies as DD, awaiting more detailed fieldwork in northern Vietnam.

Cultivation. Rhododendron chunii subsp. vietnamense can tolerate full sun or partial shade and is hardy down to a minimum temperature of approximately $-8^{\circ} \mathrm{C}$. It requires damp, 

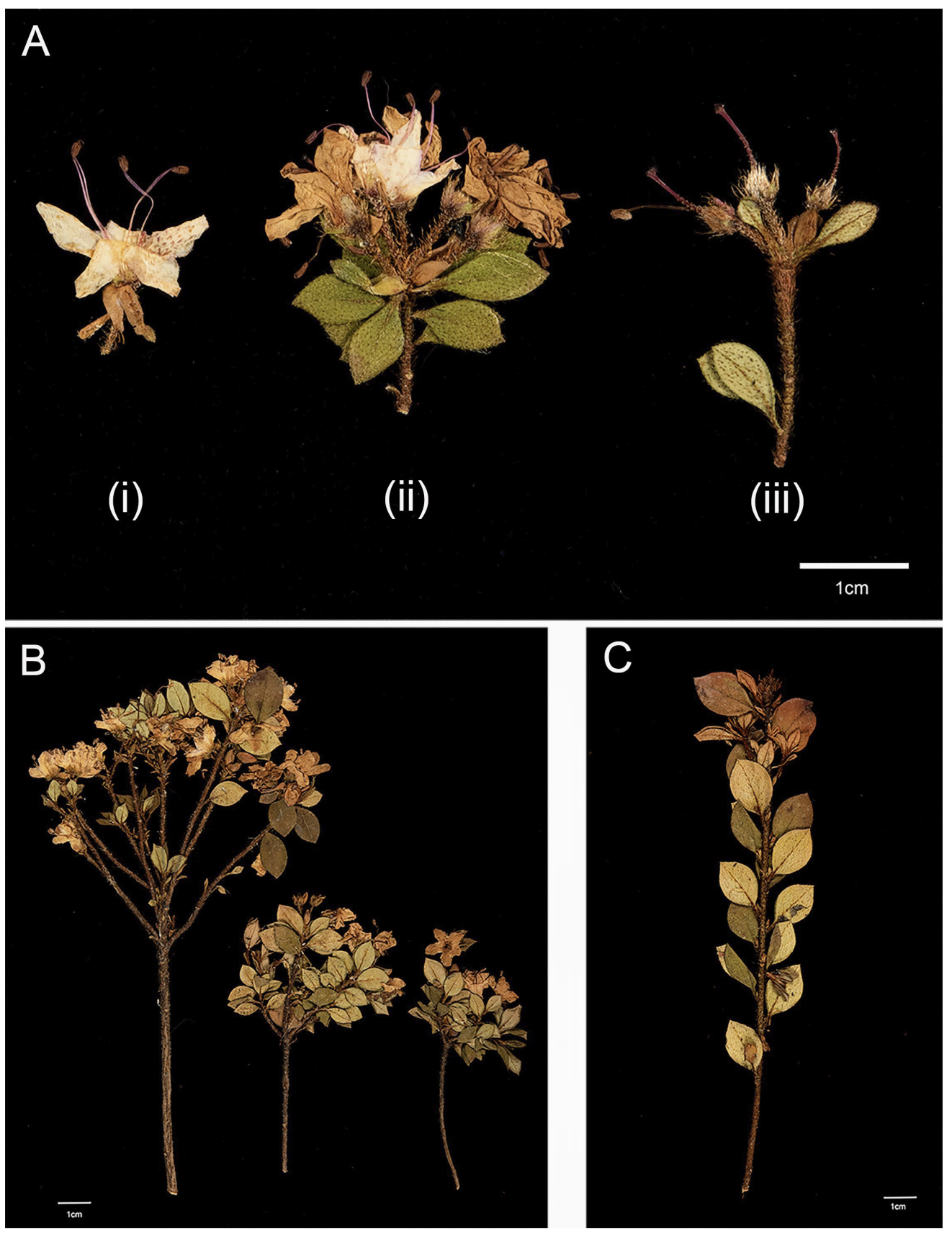

Figure 4. Rhododendron chunii subsp. vietnamense R.A.Baines \& D.F.Chamb., subsp. nov. A, Floral parts highlighting tubular corolla, stigma and style (i), floral arrangement in terminal cluster (ii), and seed capsules (iii); B, flowering stem in cultivation; C, young stems with erectopatent bristles. Photographs: L. Wilson. 
acidic soils that are freely draining but high in organic matter. When propagated from seed it can produce flowers in its third year and should reach a maximum height of $1 \mathrm{~m}$.

Additional specimens examined. VIETNAM. Lao Cai Province: Sa Pa District, Phan Xi Păng Mountain, $2605 \mathrm{~m}, 22^{\circ} 19.208^{\prime} \mathrm{N}, 103^{\circ} 46.191^{\prime} \mathrm{E}$ [22 $\left.{ }^{\circ} 19^{\prime} 12.46 " \mathrm{~N}, 103^{\circ} 46^{\prime} 11.46^{\prime \prime} \mathrm{E}\right], 1$ xi 2014, Baines et al. HNE 160 (source of seeds for RBGE accession 20150480) (E, HN, K). Sa Pa, Phan Xi Păng, Ton Station, 2605 m, 1 xi 2014, Hanoi, UBC, Logan, Longwood \& Kew Expedition to Vietnam (2014) HNE 163 (E [E00787050, E00787049]). Vietnam, screes on banks of a river above second camp and below Phan Xi Păng, 2300 m, 8 v 1992, K. Rushforth 2266 (E [E00039842]); ridge from Sin Chay village to first campsite, 2350 m, 3 v 1992, K. Rushforth 2242 (E [E00039840]); Camp 2 to the summit, narrow belt above first rock outcrop, 2550 m, 27 x 1994, K. Rushforth \& D. Chamberlain, Rushforth 3011 (E [E00073374]).

Nguyen \& Nguyen (2012) reported the existence of Rhododendron chunii in Vietnam, we assume based on the Rushforth specimens cited above. We are now aware of several collections of subsp. vietnamense that are consistent in the diagnostic morphological characters that distinguish this taxon from subsp. chunii. However, these are relatively trivial compared with the obvious similarities between the two subspecies. Furthermore, there are very few specimens available to us of subsp. chunii. We therefore cannot comment on the range of variation in the Chinese populations.

Subspecies chunii occurs at an altitude of 1100-1800 $\mathrm{m}$ in forested mountains in northern Guangdong Province, South China.

\section{Acknowledgements}

We would like to thank Mark Newman for his critical comments on this manuscript. We are grateful to L. Wilson for the photographs and to $\mathrm{Dr}$ J. Grimshaw and Andrew Luke for supplying additional herbarium material.

The Royal Botanic Garden Edinburgh (RBGE) is supported by the Scottish Government's Rural and Environmental Science and Analytical Services Division. R. Baines and V. D. Nguyen would like to thank the Vietnamese Institute of Ecology and Biological Resources (IEBR), the University of British Columbia, Logan Botanic Garden, Longwood Gardens, and the Royal Botanic Gardens, Kew for supporting the 2014 expedition to northern Vietnam. The expedition was funded by the Stanley Smith Horticultural Trust, the Royal Horticultural Society Bursary Fund, the RBGE Expedition Fund and the Vietnam National Foundation for Science and Technology Development under grant no. 106.03-2017.300 (B. H. Quang).

\section{References}

Critical Ecosystem Partnership Fund. 2020. Ecosystem Profile. Indo-Burma Biodiversity Hotspot, 2020 Update. https://www.cepf.net/sites/default/files/indo-burma-ecosystem-profile-2020-update.pdf Gibbs D, Chamberlain D, Argent G. 2011. The Red List of Rhododendrons. Richmond: Botanic Gardens Conservation International. 
IUCN Standards and Petitions Subcommittee. 2019. Guidelines for Using the IUCN Red List Categories and Criteria, version 14. Prepared by the Standards and Petitions Subcommittee. Downloadable from http://www.iucnredlist.org/documents/RedListGuidelines.pdf.

Mackay M, Hootman S, Smith G, Thomson D, Gardiner S, Smith P. 2018. Updated Global Analysis for Ex Situ Conservation of Rhododendron L. (Ericaceae). Report to Botanic Gardens Conservation International (Richmond, UK), Massey University, Palmerston North, New Zealand, and Botanic Gardens Conservation International.

Nguyen TH, Nguyen T. 2012. New records of two species of Rhododendron for the flora of Vietnam. Journal of Biology (Vietnam). 34:446-451. 